\title{
THE INFLUENCE OF DIFFERENT FEED ADITIVES TO PERFORMANCES AND IMMUNE RESPONSE IN BROILER CHICKEN
}

\author{
TOKIC VESNA*, LAZAREVIC M**, SINOVEC $Z^{* *}$ and TOKIC A* \\ *School of agriculture and veterinary medicine, Svilajnac, Serbia \\ **Faculty of veterinary medicine, Beograd, Serbia \\ (Received 26. October 2006)
}

Our investigations were conducted in order to determine the influence of mannan-oligosaccharide (MOS) based prebiotics and polysaccharide microelement complexes on the performance and immune response of Arbor Acre broiler chickens. Total of 186 chickens was included in the study which lasted 42 days. Birds were fed ad libitum three different complete food mixtures (from days 1- 21, 21 - 35 and 35-42) according to the standard fattening procedure. Mixtures for chickens from the first group were supplemented with mannanoligosaccharide based prebiotics and for the birds from the second group with polysaccharide microelement (Fe, $\mathrm{Cu}, \mathrm{ZN}$ and $\mathrm{Mn}$ ) complexes.

Broilers in the control group had daily weight gain of $49.1 \mathrm{~g}$, daily food consumption of $115.5 \mathrm{~g}$ and a feed : gain ratio 2.35. In the group of broilers feed mixtures supplemented with mannan-oligosaccharides, the daily weight gain was higher (+ 14.95\%), daily food consumption was lower (-2.67) and feed : gain ratio was smaller (-15.32\%) when compared to the control group. In the group of broilers fed mixtures with polysaccharide microelement complexes, the daily weight gain was also higher (+ 11.43\%), daily food consumption was lower (-4.28) and feed:gain ratio was smaller (-14.0\%) when compared to the control group.

Following revaccination against NCD, broilers fed MOS based prebiotics had significantly higher titers of antibodies than observed in the other two groups. The highest degree of cutaneous hypersensitivity to PHA was recorded in the group of broilers fed mixtures with polysaccharide microelement complexes.

Key words: broilers, fattening, mannan-oligosaccharides (MOS), polysaccharide microelement complexes, immune response

\section{INTRODUCTION}

During the second half of the last century, animal production was characterized by extensive use of antimicrobial drugs in sub-therapeuthical doses 
as growth promoters. This resulted in the occurrence of resistant microorganisms which became one of the major problems in human medicine. Thus, the use of antimicrobial drugs in feed mixtures for animals is completely banned in EU, starting from the beginning of this year. Such, doubtlessly useful decision gave rise to new problems for breeders, veterinarians and nutritionists: how to ensure, under new rules, animal health in intensive production along with a satisfactory cost/benefit ratio? Among others, two possible ways for reaching this goal are the use of organic microelement forms and prebiotics.

Animals need microelements only in small quantities but they are essential for health, reproduction and production, being included in all physiological and biochemical reactions and processes. In intensive production it is necessary to add microelements in sufficient amounts to meet the enhanced requirements due to increased demands. It is also very important to estimate their bioavailability, which is usually defined as the part of a nutrient that can be used within the animal's body (Forbes and Erdman, 1985). Bioavailability represents the amount of an element that can be absorbed and is available to the organism for metabolic reactions or deposition. In everyday practice, the inorganic forms of microelements are usually used to satisfy the needs of the animals, but some novel data confirms numerous advantages of so called "organic" or "helate" forms. In this group, amino-acid helates and peptide helates or their mixtures (bioplexes) are now extensively used. It is documented that helate forms of microelements are protected in the gastrointestinal tract (GIT) because they don't have an electric charge and therefore are not influenced by pH changes (Lyons, 1994). Moreover, their absorption is enhanced due to their electroneutrality and the possible role of amino acids as carriers. During the last decade, polysaccharide complexes were also introduced in animal's production as new organic microelement forms (Gallaher et al., 1999). While proteinates are formed by chemical procedures, these forms are being produced by specific hydrothermal procedures that enable the formation of electrostatic bonds between positively charged metal ions and negatively charged ions on the polysaccharide molecules derived from sea algae. This complex protects microelements from the interactions in the upper parts of GIT, especially the bowel. In the small intestine complexes are being hydrolyzed under the activity of pancreatic amylase and microelements are gradually released and absorbed during a prolonged period of time (Salzer et. al.,1997). Microelements forming polysaccharide complexes do not react with other minerals. This enables a more efficient absorption and higher bioavailability (from 2.5 to 3.2 times) as compared to sulphate or oxide forms (Ho and Hidiroglou, 1997 ) and leads to improvement of performance as proved in trials on calves and piglets (Staem and Geyer, 1988). Same authors stated that reproductive performance of cows and sows was also improved when they consumed feed mixtures supplemented with polysaccharide forms of microelements.

Prebiotics are nondigestable feed components that act beneficially on the animal's health status by selective stimulation of certain bacteria in the GIT and/or preventing growth or adherence of pathogenic microorganisms (Gibson and Roberfroid, 1995). Prebiotcs also exert positive systemic effects following absorption of the products generated by bacterial fermentation. They are not 
digestible in the upper parts of GIT being used only by beneficiary bacteria, mainly in the colon. Numerous prebiotics are "non starch" carbohydrates but some peptides and proteins may also fall into this group (MacFarlane and Cummings, 1991). Two main groups of prebiotics are fructo-oligosaccharides (FOS) and manan-oligosaccharides (MOS). Oligosaccharides consist of 2-10 monosaccharide units connected by glycosidic bonds between hemiacetal or hemiketal groups with the hydroxyl group of the next sugar molecule. Fructoologosaccharides are used in human medicine for the control of diarrhea (Spiegel. et al. 1994), for lowering high blood pressure and normalization of the glucose and lipid levels in the serum (Yamashita, 1984). They have been used in veterinary medicine to control salmonella infections (Oyrizabai, 1995). Manan oligosaccharides are mannose polymers consist of the main mannose chain $(\alpha-1$ $\rightarrow 6$ bounds) and several small "branches" (1-3 mannose molecules) connected by $\alpha-(1 \rightarrow 2)$ or $\alpha-(1 \rightarrow 3)$ bonds. They represent up to $30 \%$ of the yeast cell walls (Phaff and Kirtzman, 1984). The main principle of the MOS action is based on their compatibility with lectins found on the pile and fimbrae of some enteropathogenic bacteria. As bacteria attach to the mucous intestinal surface by lectins, blocking these molecules by MOS prevents their pathogenic effects. Many bacterial strains (66\% of E. coli and $53 \%$ of Salmonellae) have mannose "sensitive" adhesive molecules (Sharon and Lis, 1993). Moreover, it is postulated that mannans can detach already attached E.coli after only $30 \mathrm{~min}$. of exposure to MOS molecules (Newman, 1994). Broilers fed MOS supplemented feed mixtures had a significantly lower incidence of infections with Salmonella typhimurium and Dublin (Newman 1996), Campylobacter jejuni (Shoeni and Wong, 1994) and E. coli (Spring, 1996). Selectivity of the MOS effects on pathogenic bacteria is based on the fact that bacteria belonging to Lactobacillus and Bifidobacterium strains have the enzyme mannase that degradates MOS molecules. MOS can also bind to some toxins, viruses and eukaryotic cells (Stanley et al., 1993; Devegowda et al., 1994; Stanley et al., 1998). It is also documented that MOS can exert beneficiary effects in some cases of other bacterial infections, and even in cases of tumor occurrence in dogs and cats (Mizuno et al., 1995; Suda et al., 1995; Harris et al., 1991). Savage et al. (1996) showed that MOS supplementation of turkeys, enhances Ig $\mathrm{G}$ and Ig A production. These findings were later confirmed by Ewing and Cole (1994), Newman (1994), MacDonald (1995) and Verword (1997). Newman (1994) postulated that MOS molecules have an adjuvant effect enhancing antibody production to several antigens. The precise mode of the MOS action on immune response is not clear but it was documented they it influences functions of monocites and macrophages (Kokoshis et al., 1978), elevates arachidonic acid production (Kennedy et al., 1978), elevates the release of leukotriens (Peterson et al., 1994), interleukines (Adachi et al., 1994; Flory et al., 1995), interferons (Sakurai et al., 1995) and tumor necrosis factor (TNF) (Joault et al., 1995; Ohno et al., 1995; Okazaki et al., 1995; Soel et al., 1995).

There is some disagreement in the literature regarding the possible effects of MOS on the digestibility of other feed components. It is now accepted that oligosaccharides do not have a significant influence in that prospect (Carre et al., 1995; Durst, 1996; Trevino et al., 1990). The positive influence of MOS in feed 
mixtures on broilers performance is well documented (Kuprecht et al., 1998; Roch, 1998; Petersen, 1998; Newman, 1999; lji and Tivei 1998; Pupavac et al., 1998). Numerous investigations were set up in order to estimate optimal MOS concentration fattening of broilers and some new data suggests the following scheme: $0.2 \%$ during the first week, $0.1 \%$ during the second week and $0.05 \%$ until the $42^{\text {nd }}$ day (Hooge, 2003).

The aim of this study was to investigate the influence of polysaccharide bound microelements ( $\mathrm{Fe}, \mathrm{Cu}, \mathrm{Mn}$ and $\mathrm{Zn}$ ) and mannan-oligosaccharides on the broilers performances and their immune response.

\section{MATERIALS AND METHODS}

Animals. Arbor Acre broilers were obtained from a commercial hatchery. The trial was performed on a total of 186 one day-old chickens with 62 broilers in each group, housed in wire floor battery brooders. Light-dark cycle, temperature and moisture were maintained constant throughout the trial.

Diets. All groups of broilers were fed with a feed mixture that consisted of standard feedstuffs and contained enough nutrients to satisfy the requirements of this category.

Table 1. Chemical composition of the feed for broilers

\begin{tabular}{|l|c|c|c|}
\hline \multirow{2}{*}{ Chemical composition } & \multicolumn{3}{|c|}{ \% of mixture } \\
\cline { 2 - 4 } & $1-21$ day & $21-35$ day & 35-42 day \\
\hline \hline Water & 10.96 & 11.32 & 11.58 \\
\hline Ash & 5.47 & 5.16 & 4.79 \\
\hline Proteins & 22.38 & 19.51 & 17.27 \\
\hline Fat & 6.87 & 6.01 & 5.50 \\
\hline Celulose & 3.14 & 3.00 & 3.00 \\
\hline FNE & 51.18 & 55.00 & 57.86 \\
\hline Ca & 1.03 & 0.94 & 0.81 \\
\hline P & 0.76 & 0.70 & 0.60 \\
\hline ME, MJ/kg & 13.11 & 13.17 & 13.21 \\
\hline Lysine & 1.34 & 1.11 & 0.92 \\
\hline Methonine + cystine & 0.85 & 0.70 & 0.50 \\
\hline
\end{tabular}

FNE - free nitrogen extract

$\mathrm{ME}$ - metabolizable energy

In the feed for the first experimental group (E I), $0.2 \%$ of Bio Mos (Alltech, USA) was added while for the second (E II), group $30 \%$ of microelements $(\mathrm{Fe}, \mathrm{Cu}$, $\mathrm{Zn}$ and $\mathrm{Mn}$ ) was provided from SQM (QUALI TECH, USA) and 70\% from usual 
inorganic salts. Control group (C) was fed standard broiler mixtures conteaning only inorganic forms of the microelements.

Data and sample collection. Performance and health status were monitored during the whole trial period. Body weight (BW) was measured on days 1, 21, 35 and 42 , and feed consumption was recorded every day and calculated for the same intervals. From the measured data, average daily gain (ADG) and gain:feed ratio (GFR) were calculated.

Vaccination. All birds were vaccinated with Galivet La Sota (VZ Zemun) on day 10 and revaccinated on day 17 of the trial. Blood samples were taken on days 10,30 and 40 by cardiac puncture from 10 animals from each group and thereof these birds were excluded from the trial. The titers of antibodies were estimated by HI method (Mannuel OIE, 1996).

CBHR test. The test for cutaneous basophil hypersensitivity to phytohemagglutinine (CBHR) was performed by intradermal innoculation of $100 \mathrm{mg}$ of PHA (INEP, Zemun) dissolved in $0.1 \mathrm{~mL}$ of phosphate buffered saline (PBS), pH 7.2, between the $3^{\text {rd }}$ and $4^{\text {th }}$ toe of the left foot (Corrier and De Loch, 1990; Miljkovic, 1993). The same amount of PBS was inoculated into the right foot as a control and $24^{\text {hrs }}$ later, the skin thickness was measured on both legs using an adapted cutinometer. The difference between the thickness of the left and right interdigital space was calculated and taken as the CBHR in $\mathrm{mm}$.

Statistical analysis. All data was statistically processed using MS Excel 97 and SPSS 10.0 software by calculating the standard statistical parameters: mean value, standard deviation, standard error, variation coefficient and interval of variations. Significance of differences between the mean values was estimated by Student's t test.

\section{RESULTS AND DISCUSSION}

The performance of Arbor Acre broilers differed between control and experimental groups upon the additive used, as shown in Tables 2,3, and Figures 1 and 2. At the beginning of the trial (day 1), body mass of chickens in all groups didn't significantly differ. During the trial, the body mass of birds in the control group was under the technological limits typical for this provenience, age and breeding conditions. In all phases of the experiment, broilers feed mixtures supplemented with prebiotic or organic microelemnt forms had higher mean body mass and these differences were statistically significant $(p<0.05)$ (Table 2$)$.

Average daily weight gain values were, during the trial, under technological limits for this category and strain (Table 3). Broilers from E - I and E - II groups achieved significantly higher daily weight gain compared to the control. 


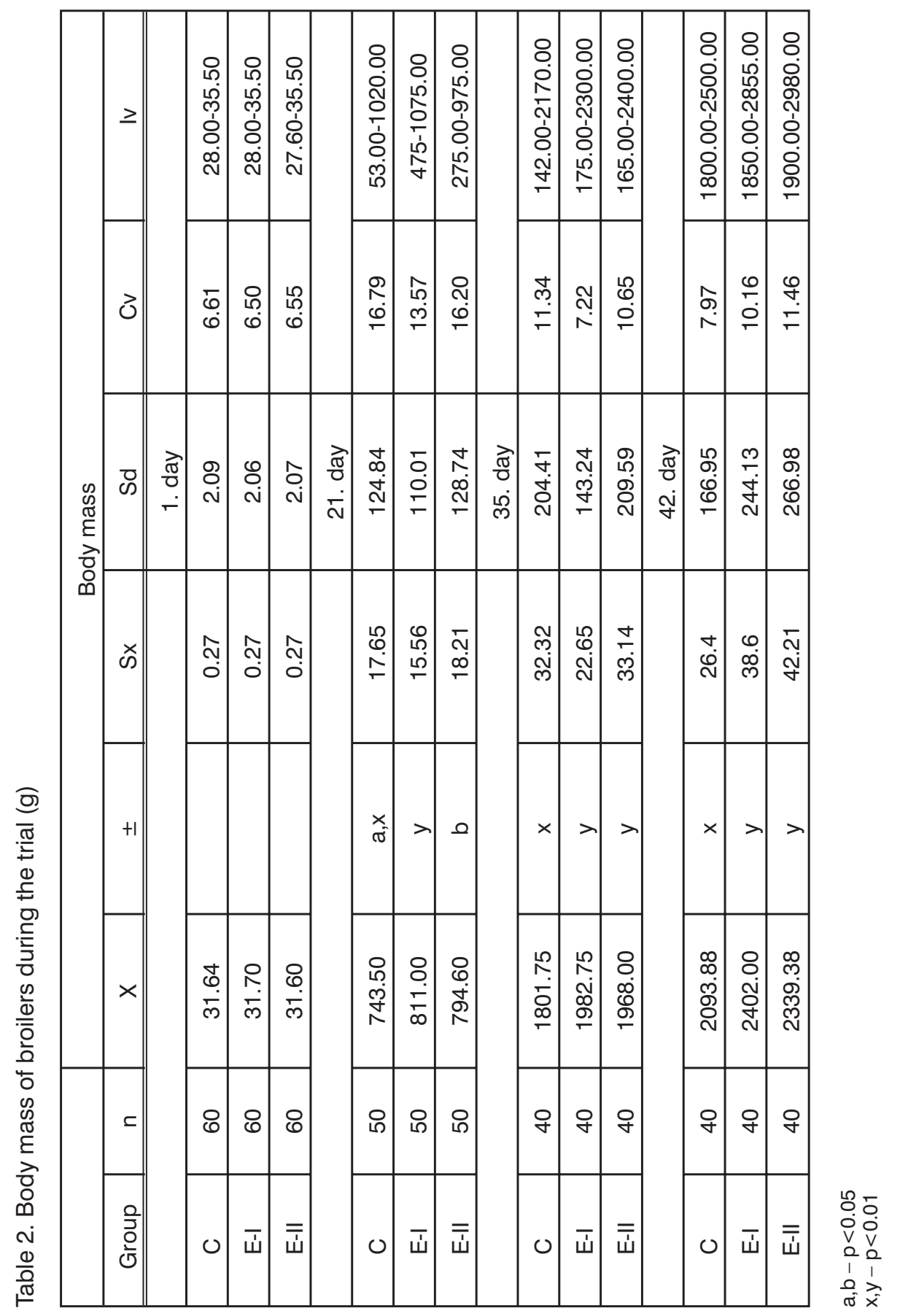


Acta Veterinaria (Beograd), Vol. 57, No. 2-3, 217-229, 2007.

Tokić Vesna et al.: The influence of different feed aditives to

performances and immune response in broiler chicken

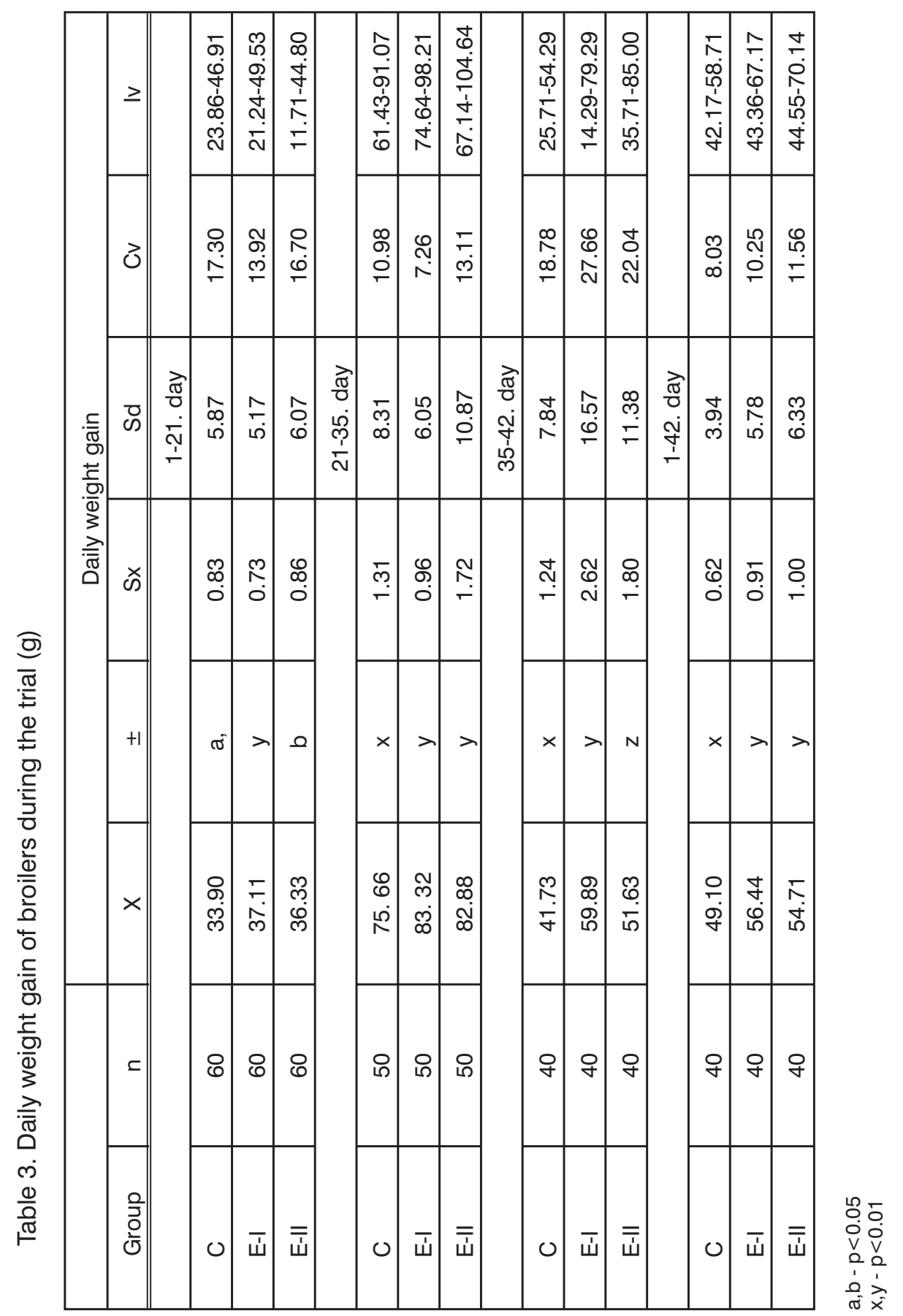




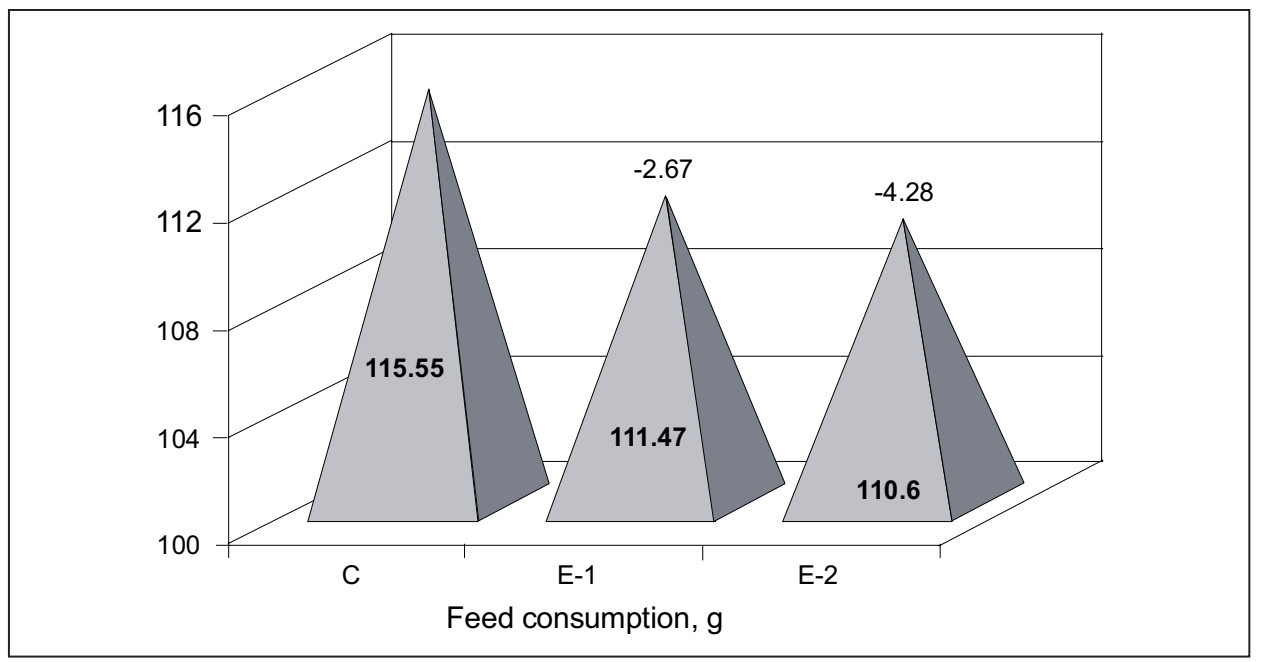

Figure 1. Daily feed consumption in broilers

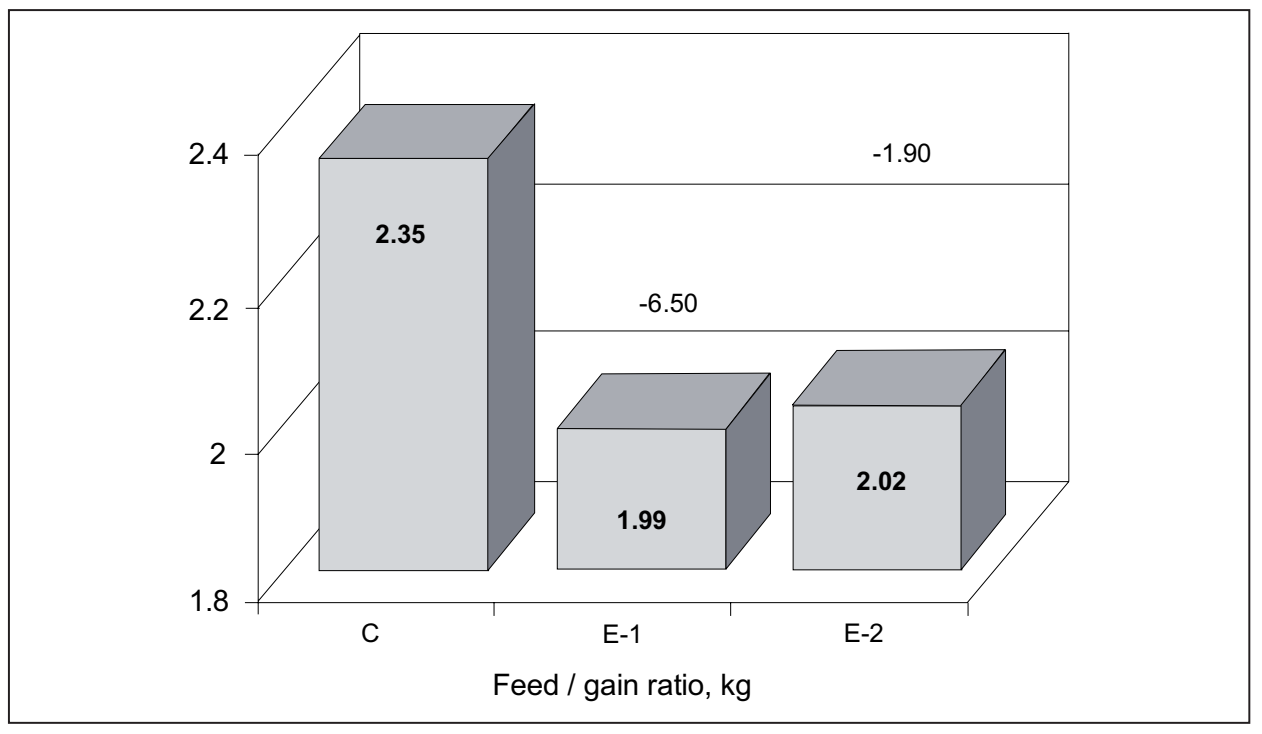

Figure 2. Broilers feed:gain ratio (control $=100 \%$ )

Daily feed consumption (DFC) in broilers was also influenced by experimental treatment and supplementation with Bio Mos and organic forms of microelements (SQM) resulted in lower DFC values for 2.68 and $4.28 \%$ respectively. 
Feed:gain ratio was also influenced by treatments. Broilers in groups E - I and $E$ II had feed conversion of 1.99 and 2.02 respectively. This value in the control group was 2.35. Benefical effects of MOS as a growth promoter were also documented in turkeys (Sims et al., 2004).

At the beginning of the trial, in all groups, low titers of maternal antibodies to NCD virus were recorded. Following revaccination (day 17), on day 30 , the values obtained for the $\mathrm{E}$ - I group were significantly higher when compared to groups $\mathrm{C}$ and $E$ - II $(p<0.01)$. A similar phenomenon was observed on day 40 , although titer values were lower in all groups (Table 4). Our results are in agreement with those from Upendra (1999). This enhancement in immune response via a nutritional route could play an important role in improving bird health.

Table 4. Mean titer values of antibodies to NCD virus in broilers

\begin{tabular}{|c|c|c|c|}
\hline Group & C & E-I & E-II \\
\hline \hline 10 days & $2.28 \pm 0.75$ & $4.00 \pm 2.82$ & $4.00 \pm 2.82$ \\
\hline 30 days & $34.28 \pm 21.52^{\mathrm{a}}$ & $118.85 \pm 68.41^{\mathrm{b}}$ & $36.28 \pm 14.39$ \\
\hline 40 days & $16.00 \pm 8.00^{\mathrm{x}}$ & $68.57 \pm 28.79^{\mathrm{x}, \mathrm{y}}$ & $32.43 \pm 2.22^{\mathrm{y}}$ \\
\hline
\end{tabular}

$a, b-p<0.05$

$x, y-p<0.01$

During the trial, values observed for the degree of CBHR were significantly higher in the experimental groups when compared to the control (Table 5). The differences between E - I and E - II groups were noticeable only at day 10. The degree of CBHR in the control group was similar as stated by Rusov et al. (1997). As $\mathrm{CBHR}$ is an indicator of the cellular immune response we may conclude that the used feed additives up regulated the activity of T cells. We may assume that a more intensive CBHR might be a consequence of better Zinc supplementation. Among all microelements, zinc is probably the most important for immune reactivity (Wellinghausen et al., 1997). Our results concerning the intensity of CBHR are in agreement with findings of Cotter (1997) who found a higher degree of wattle swelling $24^{\mathrm{hrs}}$ following PHA application. Interestingly, this author found a decreased degree of CBHR following repeated PHA application.

Table 5. CBHR (mm) in broilers during trial

\begin{tabular}{|c|c|c|c|}
\hline & 10. day & 30. day & 40. day \\
\hline \hline C & $0.17 \pm 0.138^{\mathrm{c}}$ & $0.14 \pm 0.053^{\mathrm{a}}$ & $0.15 \pm 0.053^{\mathrm{x}}$ \\
\hline E-I & $0.44 \pm 0.097^{\mathrm{a}, \mathrm{x}}$ & $0.44 \pm 0.282^{\mathrm{a}}$ & $0.45 \pm 0.139^{\mathrm{x}}$ \\
\hline E-II & $0.80 \pm 0.238^{\mathrm{b}, \mathrm{x}}$ & $0.60 \pm 0.238^{\mathrm{b}}$ & $0.61 \pm 0.203^{\mathrm{y}}$ \\
\hline
\end{tabular}

a,b,c $-p<0.05$

$x, y-p<0.01$ 
There is some evidence that mannans, as a dietary factor, can increase the activity of phagocytic cells (Sisak 1995, Zennoh 1995), reduce the incidence of vaccine failure (Korosi and Korosi-Molnar, 2003) and change lymophocyte proliferative response to PHA in broilers (Cotter and Weiner, 1997). Moroever, Bio Mos supplemented turkeys had higher serum Ig $\mathrm{G}$ and bile Ig A concentrations (Savage et al 1996). The progeny of broiler breeders fed Bio Mos had higher maternal antibody titers (Shashidhara and Devegowda, 2003), while in commercial layers, titers to SRBC and BSA were significanly higher (Cotter et al. 2000). It is still unclear how MOS exerts its effects on the immune system bearing in mind that practically there is no absorption of these molecules and this phenomenon deserves further investigations.

Address for correspondence:

Prof.dr Miodrag Lazarevic

Faculty of veterinary medicine

Department of physiology and biochemistry

Bul. oslobodjenja 18

11000 Beograd, Serbia

e-mail: misha@vet.bg.ac.yu

\section{REFERENCES}

1. Adachi Y, Okazaki M, Ohno N, Yadomae T, 1994, Enhancement of cytokine production by macrofages stimulated with (1-) 3-beta-D-glucan, Grifolan (Grn), isolated from Grifola frondosa, Biol Pharm Bull, 17, 1554-60.

2. Carre B, Gomez J, Chagneau AM, 1995, Contribution of oligosaccharide and polysaccharide digestion, and excreta losses of lactic acid and short chain fatty acids, to dietary metabolisable energy values in broiler chickens and adult cockerels, Br Poult Sci, 36, 611-29.

3. Correr DE, De Loach, 1990, Interdigital skin test for the evaluation of delayed hypersensitivity and cutaneous basophil hypersensitivity in young chickens, Am J Vet Res, 6, 950-4.

4. Cotter PF, 1997, Modulation of the immune response: current perceptions and future prospects with an example from poultry, In: Biotechnology in the Feed Industry, Proceedings of Alltech's $13^{\text {th }}$ Annual Symposium (Lyons TP,KA Jacques eds.) Nottingham University Press, Nottingham, U K, 195-203.

5. Cotter PF, Weiner J, 1997, Dietary Bio Mos ${ }^{\circledR}$ modulates kinetics of the phytohemagglutinin wattle reaction in chickens, Poult Sci, 76, Suppl 1, 111.

6. Cotter PF, Malzone B, Paluch B, Lilburm ms, Sefton AE, 2000, Modulation of humoral immunity in commercial laying hens by a probiotic, Poult Sci, 79, Suppl 1, 38.

7. Devegowda G, Aravind BIR, Rajendra K, Morton MG, Baburanthna A et al., 1994, A Biological approach to counteract aflatoxicosis in broiler chickens and ducklings by the use of Saccharomyces cerevisiae cultures in the feed. In: Lyons, T.P., and K. A. Jacques (eds.) Biotechnology in the Feed Industry, Proceedings of Alltech's $10^{\text {th }}$ annual symposium. Nottingham University Press, Nottingham, U. K.: 235-45.

8. Durst L, 1996, Inclusion of fructo-oligosaccharides in broiler diets, Archiv fur Geflugelkunde, 60, 160-4.

9. Ewing WN, Cole DJA, 1994, The living Gut, An Introduction to Micro-organismus in Nutrition, Context Publications, Leicestershire, UK.

10. Flory CM, Jones ML, Miller BF, Warren JS, 1995, Regulatory roles of tumor necrosis factor alpha and interleukin-1-beta in monocyte chemoattractant protein-1-mediated pulmonary granuloma formation in the rat, Am J Pathol, 146: 450-62.

11. Forbes M, Erdman J, 1983, Bioaviailability of trace mineral elements, Ann Nutr Rev, 3, $213-31$. 
Acta Veterinaria (Beograd), Vol. 57, No. 2-3, 217-229, 2007.

Tokić Vesna et al.: The influence of different feed aditives to

performances and immune response in broiler chicken

12. Gallaher D, Gallaher M, Shulman S, McElhome A, Brokken A et al., 1999, Bioavaibility of different sources of protected zinc, 10th International Symposium on trace elements in man and animal, 275-79.

13. Gibson RG, Roberfroid M, 1995, Dietary modulation of human colonic microbiota: Introducing the concept of prebiotics, J Nutr, 125, 1401-12.

14. Harris C, Pierce K, King G, Yates KM, Hall J et al., 1991, Efficiacy of acemann in treatmant of canine and feline spontaneus neoplasms, Mol Biotherm, 3, 207-13.

15. Ho K, Hidiroglou S, 1997, Effect of dietary chelated and sequstred zinc and zinc sulphate on growing lambs fed a purified diet, Can J Anim Sci, 57, 93-9.

16. Hooge MD, 2003, Dietary mannan oligosaccharides improve broiler and turkey performance: meta-analysis of pen trials around the world, Nutrional Biotechnology in the Feed and Food Industries, Proceedings of Alltech's Nineteenth Annual Symposium, Ed. TP Lyons and KA Jacques, Nottingham University Press, 113-24.

17. Iji PA, Tivey DR, 1998, Natural and synthetic oligosaccharides in broiler chicken diets, Poult Sci, 54, $2,129-43$.

18. Jouault T, Lepage G, Bernigaud A, Trinel PA, Fradin C et al.,1995, Has Swan failed?, Vet Res, 104, 329.

19. Kennedy MT, Bates PJ, Wheatley CL, Rohrbach MS, 1995, Discrete pathways for arachidonic acid release from tanin versus beta-glucan-stimulated rabbit alveolar macrophages, J Leukocyte Biol, 58, 241-8.

20. Kokoshis PL, Williams DL, Cook JA. Di Luzio NR, 1978, Increased resistance to Staphylococcus aureus infection and enhancement in serum lysozym activity by glucan, Science, 199, 1340-2.

21. Korosi L, Korosi-Molnar A, 2003, Effects of Bio Mos on production parameters and immunological status of broilers, WPSA 14th European Symposium on Poultry Nutrition, Lilehammer, Norway, Aug 10-14.

22. Kumprecht I, Zobac $P$, Siske V, Sefton AE, Spring $P$, 1998, Effect of dietary mannanoligosaccharide level on performance and nutrient utilization of broilers, Poster. In: Biotechnology in the Feed Industry. Proc. Alltechs $14^{\text {th }}$ Annual Symposium. (Ed.: TP Lyons), Nicholasville Kentacky, Enclosure code, $016 \mathrm{C}$.

23. Lyons PT, 1994, Biotecnology in the feed industry: 1994 and beyond. In: Biotecnology in the feed industry, 1-50.

24. MacDonald F, 1995, Use of immunostimulants in agricultural applications, In: Biotechnology in the Feed Industry. Proc. Alltechs $11^{\text {th }}$ Annual Symposium. (Ed.: TP Lyons) Nicholasville Kentacky. 97-103.

25. Macfarlan GT, Cummings JH, 1991, The colonic flora, fermentation and large bowel digestive function, In: The large intestine: Physiology, pathophisiology and disease, 51-92, Raven Press, New York.

26. Miljkovic B, Rusov C, Jojic Milicevic Lj, Zivkovic R, Duricic B, Ilic Z, 1993, Izucavanje hipersenzitivne reakcije na kozi pilica fitohemaglutinom, I Doza i mesto intradermalnog inokulisanja fitohemaglutinina i vreme citanja reakcije, Vet glasnik, 3, 141-8.

27. Mizuno T, Kinoshita T, Zhuang C, Ito H, Mayuzumi Y, 1995, Antitumor-active heteroglycans from Niohshimeji mushroom, Tricholma giganteum. Biosci Biotech, 59, 568-71.

28. Newman KE, 1994, Mannanoligosaccharides: Natural polymers with significant impact on the gastrointestinal microflora and the immune system. In: Biotechnology in the Feed Industry. Proc. Alltechs $10^{\text {th }}$ Annual Symposium. (Ed.: TP Lyons) Nicholasville, Kentacky.

29. Newman KE, 1996, Nutrition manipulation of the gastrointestinal tract to eliminate salmonella and inhibition of Campylobacter jejuni colonization in chicks by defined CE bacteria, Appl Environ Microbiol, 60, 1191-7.

30. Newman KE, 1999, Feeds with antibiotic growth promoters - The oligosaccharide alternative. Biotechnology Responds. Alltech's 1999 European, Middle Eastern and African Lecture Tour.

31. Ohno N, Asada N, Adachi Y, Yadomae T, 1995, Enchancement of LPS triggered TNF-alfa (Tumor Necrosis Factor) production by (1-3)-beta-D_glucans in mice, Biol Pharm Bull, 18, 126-33.

32. OIE Manual of Standards for Diagnostic test and Vaccines, Third Edition,1996. 
33. Okazaki M, Adachi Y, Ohno N, Yadomae T, 1995, Structure - activity relationship of (1-3)-beta-Dglucans in the induction of cytokine production from macrophages, in vitro. Biol Pharm Bull, 18, 1320-7.

34. Oyarzabal OA, Conner DE, Blevins WTT, 1995, Fructooligosaccharide utilization by Salmonellae and potential direct-fed microbial bacteria for poultry, J Food Prot, 58, 1192-6.

35. Petersen CB, 1998, Comparative effects of ZooLac, Bio-Mos and Bio-Pro on performance of broilers to 36 days. Poster. In: Biotechnology in the Feed Industry, Proc. Alltechs $14^{\text {th }}$ Annual Symposium, (Ed.: TP Lyons) Nicholasville Kentucky, Enclosure code, 51. 160.

36. Peterson DS, Mackintosh JB, 1994, The clinical composition and nutritive value of australian grain legumes, Graines research and development corporation, Brisbane, Australia, 10-13, 38-41.

37. Phaff HJ, Kurtzman CP, 1984, The Yeasts, a Taxonomic Study, Elsevier Biomedical Press, Amsterdam, 252-62.

38. Pupavac S, Sinovec Z, Jerković B, 1998, Rezultati korišćenja manan-oligosaharida u ishrani brojlera, Nauka u živinarstvu, 1-2, 459-71.

39. Roch C, 1998, Effect of Bio-Mos and Flavomycin on commercial broiler performance. Poster. In: Biotechnology in the Feed Industry, Proc. Alltechs $14^{\text {th }}$ Annual Symposium (Ed.: TP Lyons) Nicholasville, Kentucky, Enclosure code, 51, 163.

40. Rusov Č, Jojić-Maličević Lj, Maljković B, Živković R, Ilić Ž, 1997, Izučavanje kožne hipersenzitivne reakcije pilića lakog i teškog tipa na fitohemaglutinin, Nauka u živinarstvu, 1-2, 31-6.

41. Sakurai T, Ohno N, Suzuki I, Yadomae T, 1995, Effect of soluble fungae (1-3) - beta- D-glucan obtained from Sclerotinia sclerotiorum on alveolar macrophage, activation, Immunopharmacol, 30, 157-66.

42. Salzer M, Shurson C, Johnson L, Gallaher D, 1997, Multiple response for assesing zinc status in weanling pigs containing sub-requirement levels of $\mathrm{Zn}$ from $\mathrm{ZnO}, \mathrm{Zn}$ polysaccharide complex, and Zn methionine, J Anim Sci, 75, Suppl. 1, 27-39.

43. Savage TF, Cotter PF, Zakrzewska El, 1996, The effect of feeding a mannan oligosaccharide on immunoglobulins, plasma IgG and IgA of Wrolstad MW male turkeys, Poult Sci, 75, (suppl.1) 71:508 -16.

44. Sharon N, Lis H, 1993, Carbohydrates in cell recognition, Scientific American, 268,1,82-9.

45. Shoeni JCL, Wong ACL, 1994, Inhibition of Campylobacter jejuni colonization in chicks by defined competitive exclusion cultures, Appl Environ Microbiol, 60, 1191-7.

46. Shashidara RG, Devegowda, 2003, Effect of dietary mannan oligosaccharide on broiler breeder production trats and immunity, Poult Sci, 82, 1319-25.

47. Sims MD, Dawson KA, Newman KE, Spring P, Hoohgel DM, 2004, Effects of diatary mannan oligosaccharide, bacitracin methylene disalicilate, or both on the live performance and intestinal microbiology of turkeys, Poult Sci, 83, 7, 1148-54.

48. Sisak F, 1995, Bio Mos - mediated stimulation of phagocytosis as assessed by luminol enhaced chemiluminiscenc, Czeh Reserach Institute, Poster presented at Allech's 11th Annual Symposium, Lexington, KY.

49. Soel M, Lett F, Holveck F, Scholler M, Waschmann D, Klein JP, 1995, Activation of human monocytes by Streptococcal rhamnose glucose polymers is mediated Cd14 antigen and mannan-binding protein inhibits TNF-alpha release, J Immunol, 154, 851-60.

50. Spiegel J, Rose R, Karabell T, Frankos V, Schmitt D, 1994, Safety and benefits of fructooligosaccharides as food ingredients, Food Technology.

51. Spring $P, 1996$, Effects of mannanoligosaccharide on different cecal parameters and on cecal concentrations of enteric pathogens in poultry, PhD thesis, Swiss Federal Institute of Technology Zurich, Zurich.

52. Stanley VG, Sefton AE, 1998, Egg and serum cholesterol as influenced by mannan oligosaccharide and aflatoxin. Poster Presented at the $14^{\text {th }}$ Annual Symposium on Biotechnology in the Feed Industry, Lexington, KY, 20-22, 1998.

53. Stanley VG, Woldesenbet ROS, Hutchinson DH, Kubena LF, 1993, The use of Saccharomyces cerevisiae to suppress the effects of aflatoxicosis in broiler chicks, Poult Sci, 72,1867-72. 
Acta Veterinaria (Beograd), Vol. 57, No. 2-3, 217-229, 2007.

Tokić Vesna et al.: The influence of different feed aditives to

performances and immune response in broiler chicken

54. Steam A, Geyer H, 1998, Effect of organic zinc on horn quality in beef cattle, International Symposium on Lameness in Ruminants, 233-5.

55. Suda M, Ohno N, Adachi Y, Yadoma T, 1995, Modulation of the antitumor effect and tissue distribution of highly branched (1-3)-beta-D-glucan, Ssg, by carrageenan, Biol Pharm Bull, 18, $772-5$.

56. Trevino J, Centeno C, Brenes A, Yuste P, Rubio L, 1990, Effect of dietary oligosaccharides on the digestion of pea starch by growing chicks, Animal Feed Sci Techn, 30, 313-9.

57. Upendra HA, 1999, Studies on probiotics and mannan oligosacharide: Their effect on performance, haematology, biochemistry and immunological aspects in broiler chicks, Dissertation, Univ of agri Sci Bangalore, India

58. Verword DJ, 1997, Enteric conditions in ostrich chicks in relation to the use of mannanoligosaccharides, Poster, In: African Lecture Tour Series, Enclosure code, 51.013b

59. Wellinghausen N, Kirchner H, Rink L, 1997, The immunobiology of zinc, Immunol Tod, 18, 11, 51921.

60. Yamashita K, 1984, Effects of fructooligosaccharides on blood glucose and serum lipids in diabetic subjects, Nutr Res, 4, 961-6.

61. Zennoh L, 1995, Effect of yeast cell wall material (Bio Mos ${ }^{\circledR}$ ) on rejuvenation (stimulation of immunocytes) on spleen derived monocytes from mice, Tokyo, Japan, Poster presented at Alltech's 11th Annual Symposium, Lexington, KY.

UTICAJ RAZLIČITIH ADITIVA U ISHRANI BROJLERA NA PROIZVODNE REZULTATE I IMUNSKI ODGOVOR

\author{
TOKIĆ VESNA, LAZAREVIĆ M, SINOVEC Z i TOKIĆ A
}

\title{
SADRŽAJ
}

Cilj ovih istraživanja je bio da se ispita uticaj prebiotika na bazi mananoligosaharida i polisaharidnih kompleksa mikroelemenata (Fe, $\mathrm{Cu}, \mathrm{Zn}$ i Mn) na proizvodne rezultate i imunski odgovor brojlera hibrida "Arbor Acres". Ogled je izveden na 186 pilića podeljenih u 3 grupe i trajao je 42 dana. Brojleri su bili hranjeni ad libitum sa tri potpune krmne smeše za tov (1-21 dan, 21-35 i 35-42) u skladu sa potrebama soja.

Brojleri hranjeni smešama standardnog sirovinskog sastava i uobičajene hranljive vrednosti (kontrolna grupa) ostvarili su prosečan dnevni prirast od 49,1 g, pri dnevnoj konzumaciji hrane od 115,5 g i konverziju hrane od 2,35. Dodavanje mananoligosaharida potpunim smešama za ishranu tovnih pilića dovodi do povećanja prosečnog dnevnog prirasta za 14,95\% pri manjoj konzumaciji hrane za $2,67 \%$ i boljoj konverziji hrane za 15,32\%. Korišćenjem smeša u koje su dodavani polisaharidni kompleksi mikroelemenata postignuti su veći dnevni prirasti za $11,43 \%$, pri manjoj konzumaciji hrane za 4,28\% i boljoj konverziji hrane za 14,0\%.

Nakon sprovedenog postupka revakcinacije, brojleri hranjeni smešom sa dodatkom manan oligosaharida imali su značajno veći titar antitela na virus NCD u odnosu na kontrolnu grupu i grupu kojoj su dodavani organski vezani mikroelementi. Najveći stepen kožne reaktivnosti na PHA, kao indikator celularne imunološke reaktivnosti registrovan je u grupi brojlera hranjenih smešama u koje su dodavani polisaharidni kompleksi mikroelemenata. 